\title{
設計変更に対する鉄骨ファブリケータの意思決定の仕組み DECISION MAKING FRAMEWORK TO RESPONSE DESIGN CHANGE ORDERS IN A STEEL FABRICATOR
}

\author{
金 貞 坤*, 紀 乃 元 $^{* *}$, 角田恒男***, 古川 暁****, 古阪秀三***** \\ Junggon KIM, Naiyuan CHI, Tsuneo KAKUTA, \\ Satoru FURUKAWA and Shuzo FURUSAKA
}

\begin{abstract}
Design change orders during steel fabrication can have a tremendous negative impact on steel fabricators and general contractors mutually. Also, it is liable to take project delay and cost escalation. Such change orders are impossible to predict and it takes some time for the steel fabricator to understand the implications of changes made by the contractor and review the response scope and method properly. Additionally, steel fabricator's staffs are usually in charge of both structural steel production and responding to change orders at the same time. Therefore, it is necessary to develop an effective and reasonable decision making framework to respond design change orders and to minimize negative effects.

This paper introduces a decision making framework, developed based on ISO9000 for design change orders in a large-scale steel fabrication shop, including detailed production organization and their production works. In addition, in order to review effective methods to reduce decision making time and make decisions more rationally, we discuss an improvement method and those effects of the decision making framework as using a meeting system, attended sub-managers from departments/teams in the steel fabricator.
\end{abstract}

Keywords: Structural steel fabrication, Design change order, Structural steel fabricator, ISO9000, Decision making, Meeting system

鉄骨製作，設計変更，鉄骨ファブリケータ，IS09000，意思決定，会議体

1. はじめに

\section{1-1 研究の背景と目的}

建築プロジェクトにおける鉄骨工事は建築物の躯体を構成する重 要な工事であり、多様な生産主体の協力に基づいて行われるため、 その生産過程は複雑なものとなっている。そのため、鉄骨工事に設 計変更のような突発的な問題が発生した場合、伝達・入手された関 連情報の再検討などに一定以上の手間と時間がかかり、他工事との 業務調整や対応策の立案が困難となる場合が多い。その結果、多く の鉄骨工事においては、工期延長や工事費の上昇などの恐れが潜在 しており、生産性低下といった大きな影響をプロジェクト全体に与 えている 1)2)3)。さらに近年では、鉄骨ファブリケータ(以下、鉄骨 ファブと呼ぶ) として外国業者が参加するようになり注 1)、鉄骨工事 の施工体制がより多様化されつつあるため、鉄骨製品の生産と調達 の仕組みを安定的に構築することが重要な課題となっている ${ }^{4) 5}$ 。 前述したような設計変更対応問題を根本的に解決するためには、
鉄骨工事に関わる各生産主体の業務と情報の流れを明確化し、合理 的な設計変更対応体制を構築する必要がある。

したがってこれらの課題解決の第一歩として本稿では、鉄骨ファ ブが設計変更にどのように対応しているかを明確にすることを目的 とし、それらに関する情報提供に協力が得られ、設計変更プロセス が明確な大規模な鉄骨ファブを選定・分析することにより、設計変 更対応業務と意思決定の仕組みを考察する。

\section{1-2 既往研究の考察}

建築プロジェクトにおける設計変更の発生と対応、その影響に関 する既往研究では、Hanna ${ }^{1)} 、 \mathrm{Ibbs}^{\left.2{ }^{23}\right)}$ が プロジェクトに与える設計 変更の影響を、生産性を基に研究し、Ibbs ${ }^{6)} 、$ Lee $^{7)} 、$ Song $^{8)} 、$ Motawa ${ }^{9}$ は設計計変更対応のための業務管理モデルを開発している。また、 鉄骨ファブの生産工程と設計変更業務に関する主な既往研究では、 浦江 ${ }^{10)}$ 、蟹澤 ${ }^{11)}$ がプロジェクト事例から鉄骨生産情報の確定過程、
* 京都大学大学院工学研究科建築学専攻 博士課程 $\cdot$ 工修

** MCS スチール 会長・工博

*** MCS スチール 副社長

**** MCS スチールジャパン システム開発部長

***** 京都大学大学院工学研究科建築学専攻 准教授.工博
Ph. D. Candidate, Dept. of Architecture and Architectural Eng., Graduate School of Eng., Kyoto Univ., M. Eng.

Executive Chairman, M.C.S. STEEI PUBLIC Co, Ltd, Ph. D. Eng.

Vice President, M.C.S. STEEL PUBLIC Co., Ltd.

System Development Manager, M.C.S. STEEL-JAPAN PUBLIC Co., Ltd.

Assoc. Prof., Dept. of Architecture and Architectural Eng., Graduate School of Eng., Kyoto Univ., Ph. D. Eng. 
渡辺 ${ }^{12)}$ がアンケート調查により鉄骨生産システムの現況と問題点、 金 ${ }^{13)}$ が鉄骨ファブの設計変更対応方法などの研究がある。また、 Karumanasseri ${ }^{14)}$ が鉄骨生産計画の立案方法、Song ${ }^{15)}$ が労働生産性の 測定モデルを開発している。しかし、いずれも部分的・概念的な解 決方法に関する研究であり、鉄骨工事の設計変更対応全般を具体的 に扱った研究は少ない。

本研究は、設計変更に関する鉄骨ファブの対応を明らかにするた め、鉄骨ファブの生産組織体制や設計変更関連業務を確認、意思決 定の仕組みを実際のプロジェクトに即して実証的に分析する点に特 徵がある。

\section{1-3 研究の範囲と方法、調査対象}

\section{(1) 研究の範囲}

本稿では、鉄骨工事の設計変更対応に関する全体的な仕組みを考 察するため、先ず鉄骨製作と設計変更対応業務を担当している鉄骨 ファブを研究対象・範囲として選定し、設計変更対応業務の仕組み を分析した結果を報告する。図1にその概念を示す。

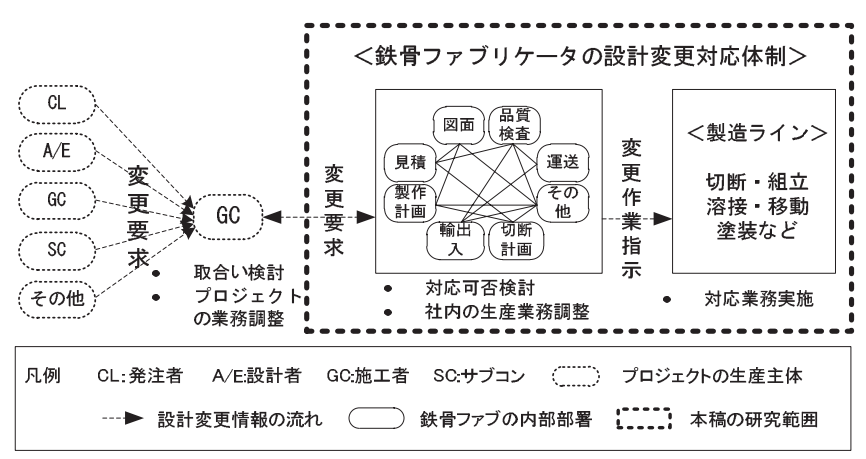

図 1 設計変更要求情報の流れと本稿の研究範囲

\section{(2) 研究の方法}

研究の方法は以下のとおりである。

(1)ヒアリングによる基礎調査を行い、鉄骨生産組織と設計変更に関 する基本的な体制や問題点を把握する。

(2)鉄骨ファブの IS09000（以下、ISO と呼ぶ) や社内の業務資料など に基づき、全般的な鉄骨ファブの生産業務と設計変更対応業務のプ ロセスを分析する。

(3)(1)と(2)の知見に基づき、鉄骨ファブの社内業務と会議に参加し、 設計変更に対する意思決定の過程と内容を考察する。

\section{（3） 調査対象の鉄骨ファブの特徵およびプロジェクト事例の概要}

調査対象とする鉄骨ファブの選定に関して、多数の鉄骨ファブを 選定・意思決定の仕組みを調べる方法と、特定の 1 社の鉄骨ファブ が一般的な鉄骨ファブといえることを確認したうえで当該鉄骨ファ ブの意思決定の仕組みを詳細に調べる方法がある。本稿では後者の 方法をとった。一般的な鉄骨ファブとして選定した根拠は、(1)国際 的な相互認証制度である ISO の認証を取得しており、また、(2)全国 鉄骨評価機構から S グレードの評価を取得しており、(3)日本の複数 のゼネコンと多数のプロジェクトでの取引実績があり、(4)当該企業 の鉄骨生産ラインはほぼ全体が情報開示されており 5)、(5)設計変更 データが詳細に情報提供されることによる。一方で、調査対象鉄骨 ファブは、(1)主生産工場が海外にあり、生産リードタイムが長く、
(2)工場の技能労働者を直接雇用しており、(3)材料調達、図面作成、 切断、製作に至る業務を一貫して社内で行っているため、全体的な 鉄骨ファブの設計変更対応業務の様子を把握することが比較的容易、 という他の鉄骨ファブと異なった特徵を有する。さらに設計変更対 応については、ISO 方式 ${ }^{16)}$ （以下、回覧方式と呼ぶ）を基に独自の やり方と文書システムを持っているなど、鉄骨生産工場と現場に対 する一貫管理体系の構築に関する検討が可能である。

また、設計変更実務を正確に理解寸るために、特殊な工法や問題 に起因寸る設計変更が多発したプロジェクトではなく、多様な内容 の設計変更が発生した 3 つのプロジェクトを対象事例として選択し た。3つの事例はいずれも異なるゼネコンが元請となった大規模な プロジェクトであり、建物の用途は事務所、事務所(官庁)、研究所 である。

表 1 はプロジェクト事例の概要を示すものであり、その中で設計 変更に関するデータは調查対象の鉄骨ファブが生産を担当した部分 に該当する。

表 1 プロジェクト事例の概要

\begin{tabular}{|c|c|c|c|c|}
\hline \multicolumn{2}{|c|}{ プロジェクト区分 } & $\mathrm{I}$ & II & III \\
\hline \multicolumn{2}{|r|}{ 建物の用途 } & 事務所 & 事務所 (官庁) & 研究所 \\
\hline \multicolumn{2}{|r|}{ 建築面積 } & 約 $11 \mathrm{fm}^{2}$ & 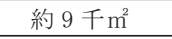 & 約 70 千 $\mathrm{m}^{2}$ \\
\hline \multicolumn{2}{|r|}{ 延床面積 } & 約 $135{\text { 千 } \mathrm{m}^{2}}^{2}$ & 約 $94{\text { 千 } \mathrm{m}^{2}}^{2}$ & 約 303 千 $\mathrm{m}^{2}$ \\
\hline \multicolumn{2}{|r|}{ 階数と棟数 } & $\begin{array}{c}\text { 地下 } 1 \text { 階、 } \\
\text { 地上 } 20 \text { 階、 } \\
1 \text { 棟 }\end{array}$ & $\begin{array}{c}\text { 地下 } 3 \text { 階、地 } \\
\text { 上 } 14 \text { 階、 } \\
1 \text { 棟 }\end{array}$ & $\begin{array}{c}\text { 地下なし、 } \\
\text { 地上 } 10 \text { 階、 } \\
5 \text { 棟 }\end{array}$ \\
\hline \multicolumn{2}{|r|}{ 軒高 } & 約 $97 \mathrm{~m}$ & 約 $68 \mathrm{~m}$ & 約 $35 \mathrm{~m}$ \\
\hline \multicolumn{2}{|r|}{ 工事期間 } & 24 ケ月 & 26.5 ケ月 & 20.5 ケ月 \\
\hline \multicolumn{2}{|c|}{ ファブ鉄骨製作期間 } & 10 ケ月 & 9 ケ月 & 5 ケ月 \\
\hline \multirow{3}{*}{$\begin{array}{l}\text { 組織 } \\
\text { 構成 }\end{array}$} & ゼネコン & 1 社 & 7 社 & 1 社 \\
\hline & 設計 & ゼネコン & 設計事務所 & ゼネコン \\
\hline & 鉄骨ファブ & 5 社 & 5 社 & 24 社 \\
\hline \multicolumn{2}{|c|}{ ファブ製作鉄骨類 } & 柱、大梁 & 大梁 & 柱、大梁 \\
\hline \multicolumn{2}{|c|}{ ファブ製作量(トン) } & 約 6,700 & 約 3,400 & 約 7,000 \\
\hline \multicolumn{2}{|c|}{ 鉄骨生産数 (個) } & 約 2,000 & 約 1,000 & 約 1,300 \\
\hline \multirow{3}{*}{$\begin{array}{l}\text { 設計 } \\
\text { 変更 }\end{array}$} & 変更件数 (件) & 74 件 & 47 件 & 156 件 \\
\hline & 変更鉄骨 (個) & 495 & 944 & 1,286 \\
\hline & 変更部品数 (個) & 約 4,000 & 約 14,8000 & 約 7,000 \\
\hline
\end{tabular}

\section{2. 鉄骨ファブの業務と生産組織体制}

鉄骨ファブの業務は、通常の生産業務と設計変更対応業務に分け られる。その二つの業務プロセスは異なっており、とりわけ設計変 更対応業務は、意思決定の過程とその結果を通常の生産業務に反映 する過程を要する。したがって、設計変更に対する鉄骨ファブの意 思決定の仕組みを明確にするためには、先ず設計変更に関する意思 決定の重要な制約条件となる生産スケジュールを生産業務とともに 理解した後、生産組織体制の観点で生産業務と設計変更対応業務を 考察する必要がある。ここでは、事例調査の結果を基に、鉄骨ファ ブの業務と生産組織体制について述べる。

\section{2-1＼cjkstart鉄骨ファブの業務と生産スケジュール}

鉄骨ファブの業務は、社内の各部署の協力によって行われるが、 通常の生産業務は各生産節の生産スケジュールを通じて管理されて いる。一般に生産スケジュールは、現場の工事日程を基に主要な業 務段階の所要期間を計算し、バーチャートなどを用いて作成される。 


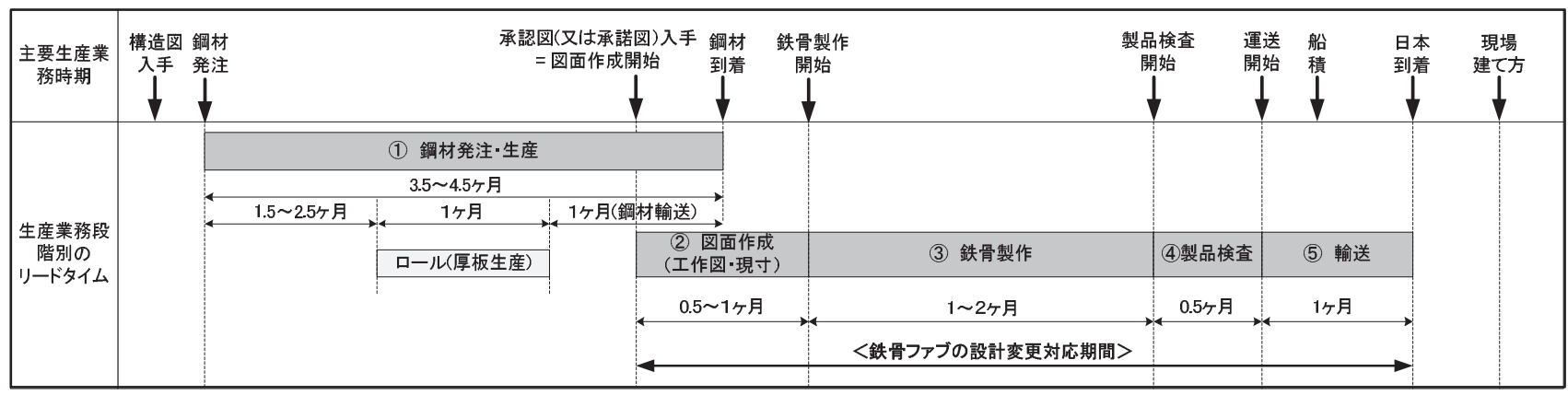

図 2 鉄骨生産リードタイム (一節の例)

そのため、生産スケジュールは設計変更に関する意思決定の主要 な制約条件となっており、鉄骨ファブの業務全体における生産スケ ジュールの有する意味を明確に理解する必要がある。本稿では、研 究対象とした鉄骨ファブの生産スケジュールの事例を調査・分析し た。

その結果、鉄骨ファブは主要業務開始時点を基に、五つの生産段 階に分けて業務リードタイムを決めている。つまり決めなければな らないリードタイムは、(1)鋼材発注（厚板など)、(2)図面作成（工作 図・現寸・切断計画・製品リスト・部品リストなど)、(3)鉄骨製作（切 断・組立・溶接・穴明など)、(4)製品検查（UT・法検查、第 3 者検 查など）、(5)輸送（運送・船積など）である。さらに実際のプロジェ クトの生産節別のリードタイムは、その生産量(ロットサイズ)と現 場日程の変動に伴い、作業・余裕期間が異なるようになっている。

生産スケジュールにおける主要業務開始時期とリードタイムの決 定方式に関する調查結果を整理して図 2 に示寸。

\section{2-2＼cjkstart鉄骨ファブの生産組織体制}

鉄骨ファブの生産組織には、直接鉄骨生産に関与寸る組織と、会 社の運営と管理を支援する組織がある。また、直接鉄骨生産に関与 する組織は、2, で述べたとおり、通常の生産業務と設計変更対応 業務を同時に担当しているが、各業務に関与する度合い（範囲や構 成）は必ずしも一定ではない。それを整理し、図 3 に表す。鉄骨フ アブの生産組織体制を見ると、製造管理、エンジニアリング業務、
プロジェクト統括管理、会社運営統括管理の四つの主な業務部門に 大別され、図面作成などの製作準備業務を行うエンジニアリング業 務と、工場内の生産活動を管理する製造管理の二つの業務部門が主 要な役割を果たしている。

しかし、調査した鉄骨ファブでは、特に現場との業務調整を円滑 に行うため、プロジェクト統括部署を別に設置し、生産スケジュー ル管理および設計変更対応などの業務を総合的に調整している。

各業務部門の主な業務内容を整理し、以下に示寸。

会社運営統括管理部門 : 会社の運営部門として会計・労務管 理、輸出入・通関管理など

プロジェクト統括管理部門：プロジェクトを統括して現場と の空口、生産スケジュール管理、設計変更管理など

エンジニアリング業務部門 (設計・見積・製作計画)：鉄骨製 作に必要な全ての情報を作成するなど

- 製造管理部門（鉄骨製作・品質管理）：鉄骨製品生産に関する 工場内での全ての業務指示と管理、品質管理、運送など

\section{3. 鉄骨ファブの設計変更対応業務}

鉄骨ファブの設計変更対応業務の把握並びに効率的な設計変更対 応業務の処理方式を検討するため、調查対象ファブの設計変更対応 業務と意思決定の仕組みを詳細に分析・考察する。なお、当該ファ ブでは、設計変更対応業務の迅速な推進のために意思決定の仕組み を改善している。

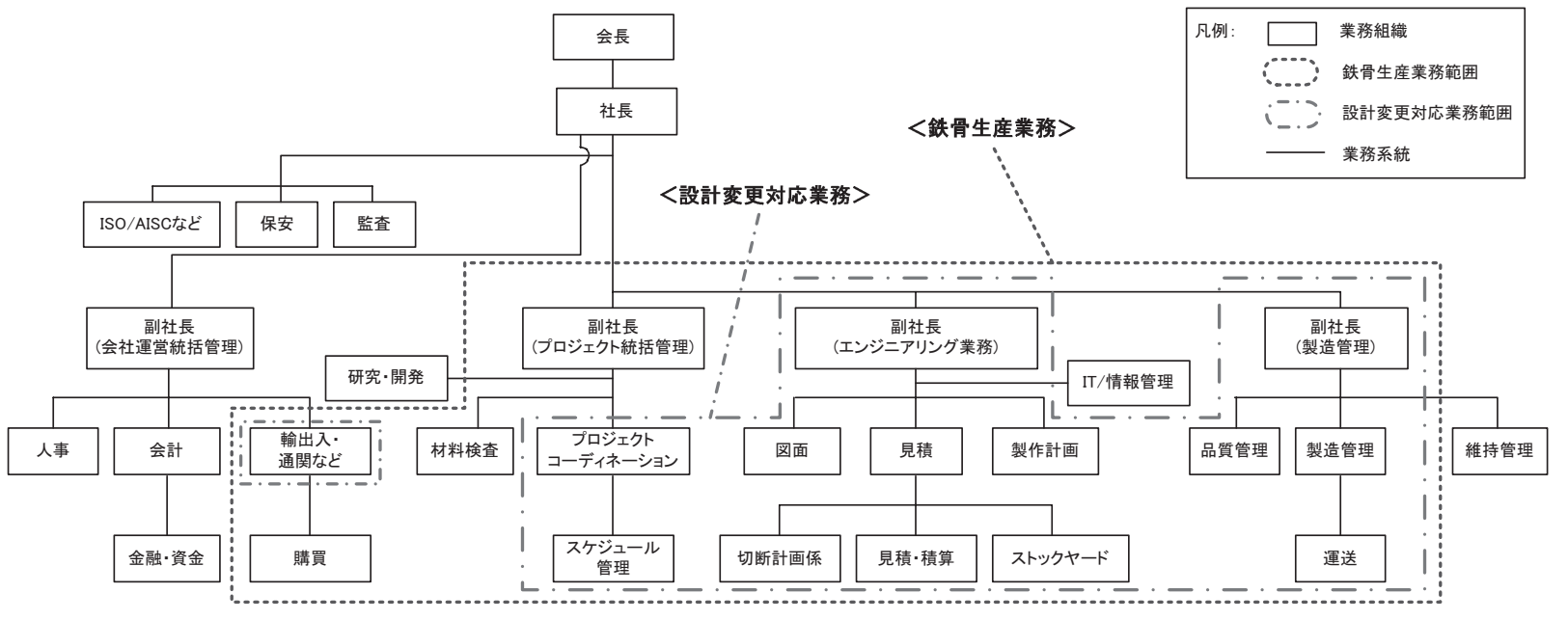

図３大規模な鉄骨ファブリケータの組織体制 (事例) 


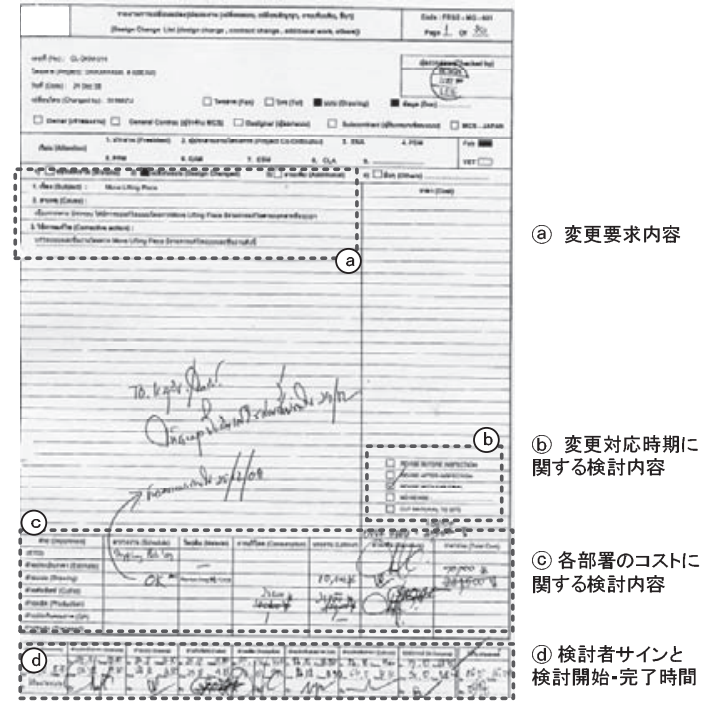

図 4 調查した鉄骨ファブの DCL 事例

\section{3-1 鉄骨ファブの設計変更対応業務（改善前）}

近年、建設分野においても社内業務と品質管理に関する体制整備 のため、ISO を導入する企業が徐々に増えている。調查した鉄骨フ アブは鉄骨生産に関わる全ての業務、とりわけ設計変更対応業務を、 ISO を用いて対応する仕組みとしている。

ISO では、設計変更対応について管理文書の表紙に、変更内容、 生産状況、検討者のサイン、検討開始・完了時間などを記入し、関 連部署が検討する回覧方式を勧告している。この鉄骨ファブも DCL (Design change 1ist) 注2) と呼ばれる一枚の文書 (図 4 ) と添付資 料を用いて設計変更対応業務を行っている。

図 5 の (A) は回覧方式を用いて設計変更対応業務の体制を構築し た設計変更対応業務プロセスの事例を分析したものである。もちろ ん、各企業の業務方式や組織体制などの違いにより、設計変更対応 業務プロセスが異なる場合が多い。

調查した鉄骨ファブは設計変更内容の検討前に図面課のマネージ ヤーが事前検討を行い、緊急の変更内容に対しては、主要部署のマ

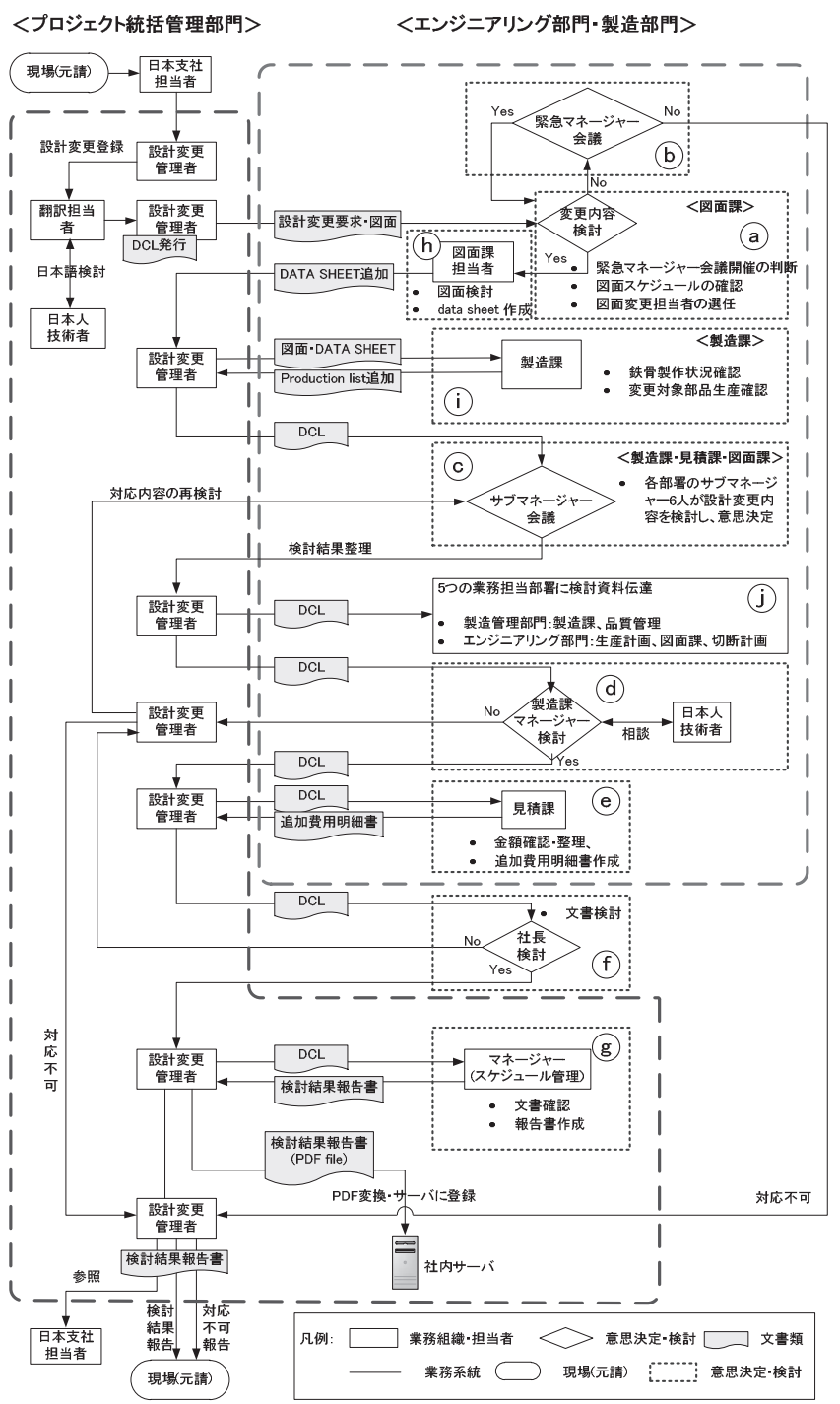

(B) 改善後

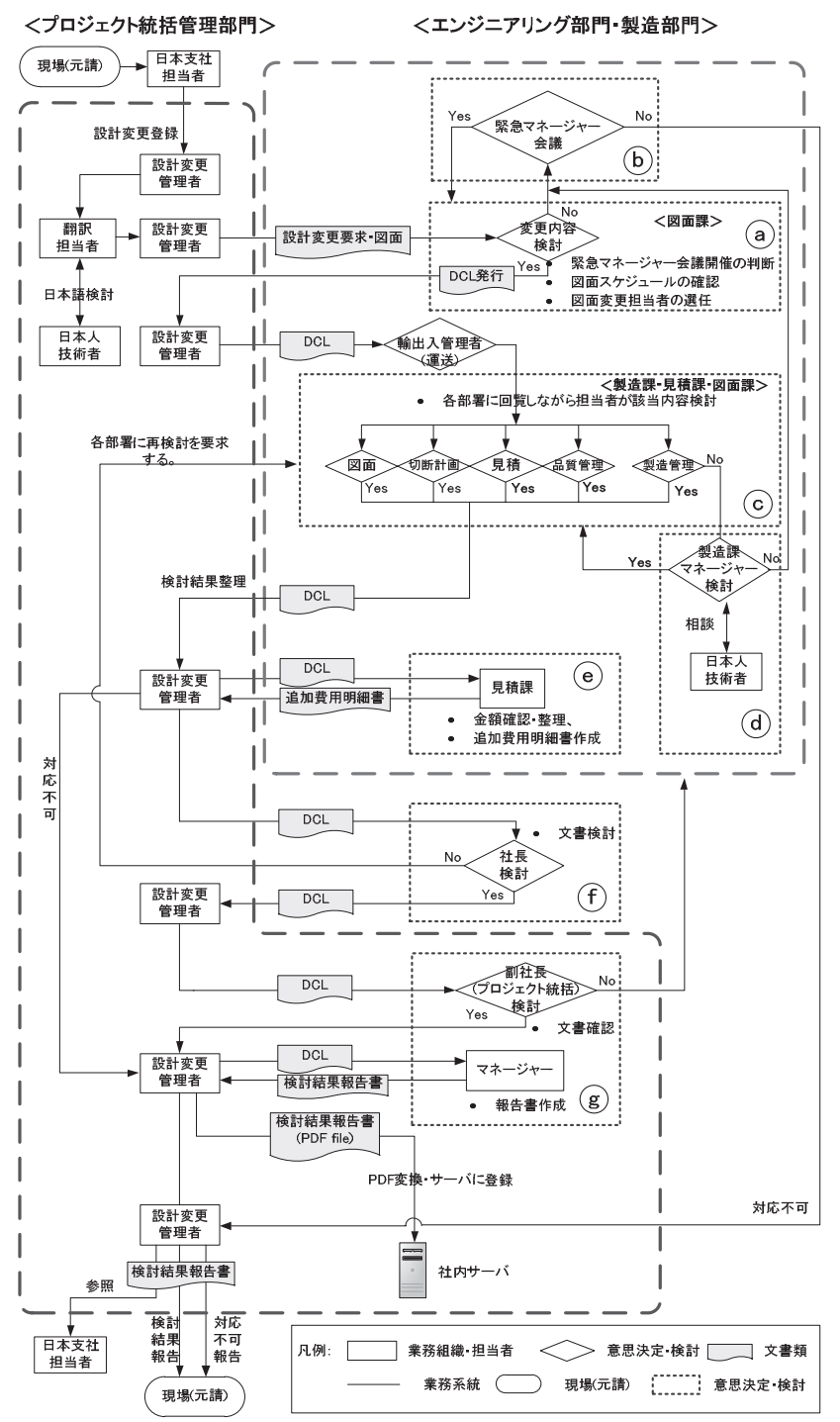

(A) 改善前

図 5 鉄骨ファブの設計変更対応業務プロセス 
ネージャー4 人による緊急マネージャー会議を通じて対応しており、 全ての設計変更対応業務にプロジェクト統括管理部門が関与してい る。また緊急ではない設計変更に対しては、各部署にDCL を回覧し ながら変更内容の検討とフィードバックを行い、意思決定の結果が 不明確な場合には再検討を実施することもある。

ここで、設計変更対応業務プロセスの全体的な効率性を論じるた めには、各対応業務の検討応答時間を用いて評価することが最もわ かりやすい方法である。そこで、プロジェクト事例を取り上げて稼 働時間 (1 日 8 時間)を基準とし、各業務にかかった平均検討応答時 間を分析した。具体的には、3つのプロジェクト事例を選択し、DCL に残っている各検討者のサインおよび検討開始と完了時間 (図 4 の (d) を基に、各検討業務にかかる平均検討応答時間を計算し、表 2 に整理して示す。

表 2 設計変更対応に関わる各業務の平均検討応答時間

\begin{tabular}{|c|c|c|}
\hline 区分 & 平均業務時間 & 備考 \\
\hline 図面 & 29 分 & 図 5 の(A)-C \\
\hline 切断計画 & 28 分 & 図 5 の (A)-C \\
\hline 見積 1 & 8 分 & 図 5 の(A)-C \\
\hline 品質管理 & 3 時間 55 分 & 図 5 の(A)-C \\
\hline 製造管理 & 11 時間 13 分 & 図 5 の(A)-(C)+@ \\
\hline 見積 2 & 2 時間 29 分 & 図 5 の(A)-(e) \\
\hline
\end{tabular}

その結果、製造管理部門における製造ラインの生産計画を調整寸 る業務に長い時間がかかっていることが分かった。その理由は、当 時製造管理部門が新プロジェクトの生産計画作成と、設計変更に対 する意思決定の結果を生産計画に反映する業務を同時に担当してお り、製造ラインの業務調整が難しくなった為である。つまり、(1)設 計変更する鉄骨の製作状況を明確に把握することに一定の時間がか かる。(2)各製造チームの作業遂行状況と鉄骨の製作状況を同時に考 慮して設計変更の対応業務時期を判断することが難しい。(3)新しい プロジェクトの作業と設計変更作業を各製作チームに配分する時に 業務の重要度や優先順位を判断することが難しい。このような理由 のために、製造ライン調整の意思決定に平均 11 時間以上かかってい る。また、品質管理課と見積課の検討にも 2 時間半から 4 時間程度 の時間が所要され、全体的な基本検討の応答時間は、18 時間以上か かっている。
ただし、このような検討応答時間の分析結果を通じて設計変更対 応業務を理解するには二つの注意を要する。第一に、実際設計変更 ごとの発生時期や業務量、各プロジェクトの遂行環境などが異なる ため、検討応答時間を直接的に比べることはできないこと、第二に、 この分析は DCL に記入されている検討業務の開始・完了時間を基に 行ったため、同時に複数の業務を行う場合の割合などは考慮してい ないことである。さらに DCL の伝達過程などにかかった時間も入っ ているため、この分析結果は設計変更 1 件当りの実平均検討応答時 間を正確に示したものであるとは言いがたい。しかし、この検討応 答時間の分析結果は、設計変更要求に対する鉄骨ファブの回答まで にかかる時間を評価することに関しては十分に意味があると考える。

\section{3-2 鉄骨ファブの設計変更対応業務の改善（改善後）}

研究対象の鉄骨ファブの生産工場は海外にあるため、運送を考慮 した、より迅速な設計変更対応などが主要な課題になっていた。こ のため、鉄骨ファブは新たな会議体注 3 )を導入することにより設計変 更対応業務の合理化を図った。

具体的には、毎日一定の時間に設計変更の意思決定に関与する各 部署のサブマネージャー6 人注4)を集め、DCL を一緒に検討し、意思 決定を行う会議体を構築した。改善後の設計変更対応業務プロセス を図 5 の (B) に示す。設計変更要求内容は、メール・fax などによる 指示と図面への書き込みで受け付け、図面担当者はこれらを分析、 変更箇所・内容をリストアップする。また、製造担当者が製造ライ ンの稼㗢状態と該当鉄骨製品の製作状況を確認する。

これらの情報はDCL の添付資料としてサブマネージャー会議で検 討される。最終的にその結果はプロジェクト統括部門を通じて各関 連部署に伝達される。このような変更対応業務における会議体の運 営とその情報の伝達過程を整理したものが図 6 である。

\section{3-3＼cjkstart設計変更対応業務の相違点と改善効果の分析}

鉄骨ファブの設計変更対応業務の改善内容を明確にするため、図 5 の (A)、（B）に示したサブマネージャー会議体導入前後の設計変更 対応業務プロセスを比較し、表 3 に示す。

図 5 と表 3 によると、(C)業務の改善により、(d) ( g)の業務が変更 され、( h、 ( I)、(1)業務が追加された。

このようなサブマネージャー会議体の導入により、設計変更対応

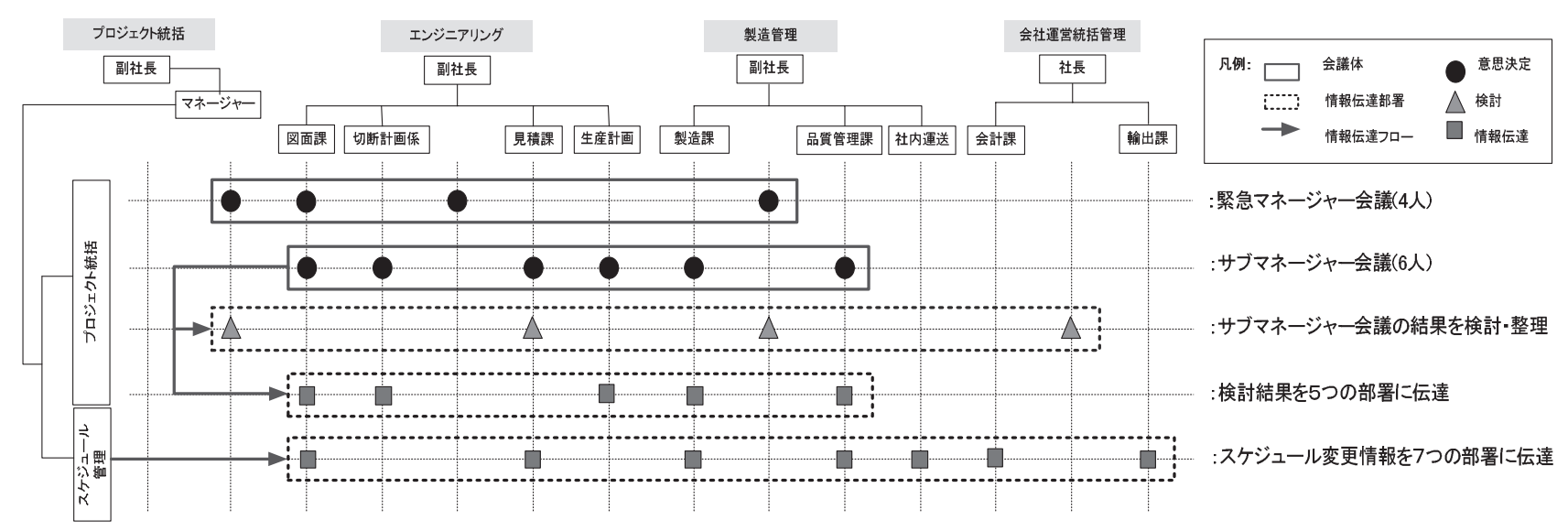

図 6 鉄骨ファブの設計変更に関する会議体と変更情報の伝達体系 (改善後) 
表 3 業務内容の相違点の比較

\begin{tabular}{|c|c|c|}
\hline & (A) 改善前 & (B) 改善後 \\
\hline (a) & \multicolumn{2}{|c|}{$\begin{array}{l}\text { 図面課のマネージャー: : 緊急マネージャー会議の開催判断、図面ス } \\
\text { ケジュールの確認と図面変更担当者の選任 }\end{array}$} \\
\hline (b) & \multicolumn{2}{|c|}{ 緊急マネージャー会議体 : 重大な変更内容に対して対応可否判断 } \\
\hline (c) & $\begin{array}{l}\text { 各部署の担当者：回覧して関 } \\
\text { 連内容を検討 }\end{array}$ & $\begin{array}{l}\text { サブマネージャー会議体:変更内 } \\
\text { 容検討・意思決定 }\end{array}$ \\
\hline (d) & $\begin{array}{l}\text { 製造課マネージャー: : 製造ラ } \\
\text { イン業務を検討・調整 }\end{array}$ & $\begin{array}{l}\text { 製造課マネージャー: : 製造ライン } \\
\text { 主要業務を検討調整 }\end{array}$ \\
\hline (e) & \multicolumn{2}{|c|}{ 見積担当者: 変更所要費用計算 - 追加費用明細書作成 } \\
\hline (f) & \multicolumn{2}{|c|}{ 社長：設計変更対応内容・文書検討 } \\
\hline (g) & プロジェクト統括 : 文書検討 & プロジェクト統括 : 文書確認 \\
\hline (h) & なし & 図面課：検討した図面と内容添付 \\
\hline (i) & なし & 製造課：鉄骨製作状況確認 \\
\hline (j) & なし & $\begin{array}{l}5 \text { つの部署:サブマネージャー会議 } \\
\text { の検討結果を通報 }\end{array}$ \\
\hline
\end{tabular}

について社内各部署間の意見交換が円滑になり、時間短縮（会議時 間は 1 時間以内に終わることが基本方針）とともにより明確な意思 決定が可能となった。これらの直接的な改善効果とともに間接的な 効果もある。例えば、(1)特殊なケース以外の設計変更対応はサブマ ネージャーが担当してマネージャーとサブマネージャーの役割分担 関係がより明確になった。(2)設計変更対応に関する各部署の文書作 成や管理などの役割分担と責任関係が確立されて業務の迅速化が可 能となった。(3)設計変更対応検討とともに、部署間で多様な情報の 交換ができる仕組みになった。

しかし、この業務改善で注意を要することとして、課題となった ことは以下のとおりである。

(1)検討応答時間の短縮と業務調整負担の減少を求める余りに拙速な 会議体の導入は、かえって無用な混乱（不明確な意思決定、複雑な 情報の流れなど）を生ずる恐れがあること。従って、実質的に改善 効果があるプロセスを中心に会議体を構築して実践に移すことが重 要である。

(2)意思決定の権限に関寸るマネージャーとサブマネージャーの役割 分担の明確化が重要であること。

(3)設計変更の重要度による意思決定の基準などを明確に定義する必 要があること。とりわけ、サブマネージャーの意思決定に関する具 体的な権限の限界範囲を提示寸る必要がある。

\section{4. 設計変更に対する意思決定の仕組み}

\section{4-1 意思決定の過程とその内容}

鉄骨ファブが行う設計変更に対する意思決定の内容は、主に二つ ある。第一は対応時期の決定である。つまり設計変更の要求時期、 例えば製作開始前、製作中、品質検査前、品質検查後などにより生 産計画・製作ライン状況などを考慮し、いつ変更作業を実施するか 決めることである。第二は対応方法の決定である。変更内容と製作 状沉によって変更部位又は部品に関する作業方法を決める。具体的 な対応方法としては、部品の追加・変更・移動・取消・切り取りな どが挙げられる。

本稿では、表 1 に示す 3 つのプロジェクト事例を取り上げ、社内 資料注 5) と担当者からのヒアリングに基づいて意思決定の過程とそ の内容を詳細に分析した ${ }^{13)}$ 。
その結果、対応時期の決定（図 4 の(b) については、製作開始の 可否 (レベル 1$)$ 、製作ラインの状況 (レベル 2)、変更処理の可能時 期 (レベル 3 ) に関する情報を用い、段階的に検討・判断している。 さらに、対応時期に関する判断を細かく分類すると、六つのタイプ にまとめられる。このように対応時期のタイプが分類される理由は、 設計変更が製造ラインに与える影響を最小にし、生産を継続しなが ら設計変更に対応寸る意思決定を行うためである。それらのタイプ を整理し、分岐ダイアグラムとして図 7 に表す。

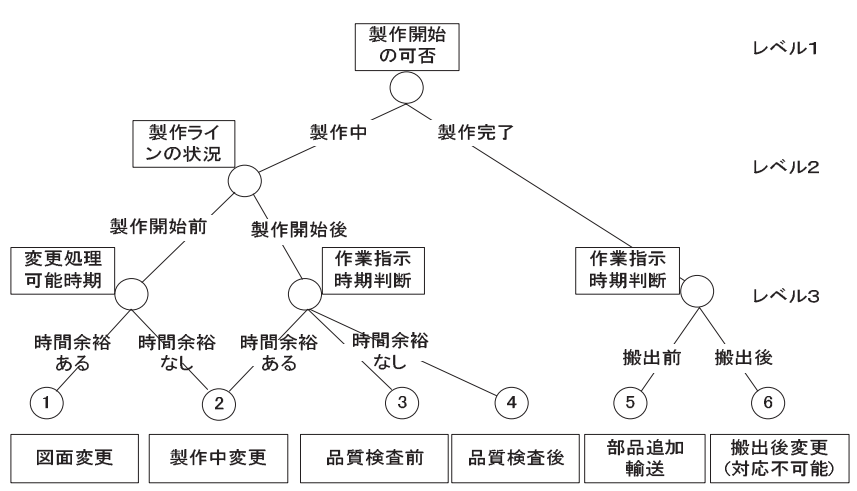

図 7 変更対応時期の判断に関する意思決定

さらに、3つのプロジェクト事例を図 7 の設計変更に対する意思 決定の対応時期によって分類し、実質的な設計変更業務量や影響を 理解するために、鉄骨単位と部品単位で設計変更頻度をカウントし たのが表 4 である。表 4 ではその頻度を、全体を 100 として(1)〜6 の区分ごとの頻度を百分率で表している。部品単位でみた場合、I · IIIフロジェクトでは 95\%以上が品質検查前（表 4 の区分(1)〜 (3)）に 変更内容を処理したことが分かる。しかし、IIIプロジェクトの場合、 I ・IIより短期間に鉄骨を製作したため、品質検查後に対応を遅延 して処理した割合が $30 \%$ を超えたが、大部分は品質検查後に対応し ても問題はさほど発生しないと言えるほど、小さなものであったこ とが予想される。ちなみに、表 4 でいう鉄骨とは柱、梁等の鉄骨製 品に製作されたものといい、部品とは鉄骨製品になる前の、厚板か ら切り出された部材のことをいう。

実際にも鉄骨ファブは、主材などの重要な変更が発生した場合、 該当鉄骨製品の製作を中断し、他の製作ラインに移動して対応し、 主材以外に関する変更は製作を継続して対応することが一般である。

表 4 設計変更対応時期に関する意思決定頻度 (事例)

\begin{tabular}{|c|c|r|r|r|r|r|r|}
\hline \multicolumn{2}{|c|}{ 区分 } & \multicolumn{1}{c|}{1} & \multicolumn{1}{c|}{$(2)$} & \multicolumn{1}{c|}{ (3) } & \multicolumn{1}{c|}{4} & \multicolumn{1}{c|}{5} & \multicolumn{1}{c|}{6} \\
\hline \multirow{2}{*}{ I } & 鉄骨 & $19.2 \%$ & $14.4 \%$ & $56.5 \%$ & $7.5 \%$ & $0.2 \%$ & $2.1 \%$ \\
\cline { 2 - 8 } & 部品 & $30.4 \%$ & $8.5 \%$ & $55.6 \%$ & $4.3 \%$ & $0.01 \%$ & $1.1 \%$ \\
\hline \multirow{2}{*}{ III } & 鉄骨 & $28.7 \%$ & $21.0 \%$ & $32.8 \%$ & $12.8 \%$ & $0.4 \%$ & $4.2 \%$ \\
\cline { 2 - 8 } & 部品 & $23.4 \%$ & $27.7 \%$ & $44.6 \%$ & $3.3 \%$ & $0.3 \%$ & $0.7 \%$ \\
\hline \multirow{2}{*}{ IIII } & 鉄骨 & $7.9 \%$ & $16.3 \%$ & $42.5 \%$ & $29.8 \%$ & $0.6 \%$ & $2.2 \%$ \\
\cline { 2 - 8 } & 部品 & $7.7 \%$ & $18.0 \%$ & $36.7 \%$ & $35.4 \%$ & $0.3 \%$ & $1.5 \%$ \\
\hline
\end{tabular}

一方、対応方法に関する意思決定については、通常、図面に表記 されている内容を図面担当者が読み取って変更対象の部品リス卜 (bi11 of material) を作成し、DCL の添付資料とする。他部署は、 
それに基づいて設計変更に対する対応業務を具体化する。例えば、 切断計画の担当者は、その部品リストと図面を用いて新たな切断計 画を作り、見積の担当者は変更対応にかかる材料量と労務量を計算 するなど、各部署はDCL を基に設計変更対応業務を行っている。

設計変更対応の具体的な内容を明確にするために、設計変更対応 を部品ごとに「追加（部品の追加）」「変更（部品寸法の変更）」「移 動 (部品位置の移動)」「取消し (部品の取り消し)」「切り取り（取 り付けた部品の切り取り)」の 5 つの対応方法に分け、それぞれの対 応方法を採用寸る頻度を、全体を 100 として対応方法の 5 つの区分 ごとの頻度を百分率で表したものを表 5 に示す。

表 5 設計変更への対応方法に関寸る意思決定内容 (事例)

\begin{tabular}{|c|c|c|c|c|c|}
\hline 区分 & 追加 & 変更 & 移動 & 取消し & 切り取り \\
\hline I & $73.1 \%$ & $18.3 \%$ & $6.0 \%$ & $2.6 \%$ & $0.1 \%$ \\
\hline II & $76.3 \%$ & $3.5 \%$ & $1.5 \%$ & $15.8 \%$ & $2.8 \%$ \\
\hline III & $70.9 \%$ & $13.9 \%$ & $8.3 \%$ & $5.8 \%$ & $1.2 \%$ \\
\hline
\end{tabular}

表 5 から次のことが言える。いずれのプロジェクトも部品の追加 業務が $70 \%$ 以上を占めている。つまり、鉄骨製作開始後になっても、 設備など他の工種との取合い検討、現場施工環境の変化、構造的な 不備の修正など様々な検討の間違いや遅れのため、部品の追加業務 が多く発生している。また、寸法変更・位置移動・部品の取消し業 務が生じる割合が、21〜28\%程度であった。また、設置した部品を 切り取る作業は、II プロジェクトの場合全設計変更部品数の $2.8 \%$ を占めているが、他のプロジェクトでは少なかった。切り取り作業 が多く発生すると製作費が高くなり、鉄骨ファブの生産性も低下寸 る。特に、II プロジェクトの場合 7 社のゼネコンが工事を分担した ため、一回変更した鉄骨を再度変更したケースもある。

このような対応時期と対応方法に関する二つの意思決定の内容は、 明確に分けられるものではなく、両方を考慮しなければならない。 例えば、製作完了後に部品を変更した場合、まず取り付けた部品を 切り取り、新たな部品を追加する。

一方、製作開始前に部品を変更した場合、図面変更のみで対応で きる時もあれば、変更部品を除いて製作を継続して対応する時もあ る。さらに意思決定過程では、この二つの情報と共に変更に要する 費用・必要材料の保有状況・新たな切断計画に関する検討も行われ る。
上述のような比較的対応しやすいものもあれば、幾つかの困難な 状況も起こりうる。たとえば、設計変更一件で数多くの製品・部品 が関わるもので、製作開始後に変更要求があった場合、主要部材の 材料不足が発生することがある。また、設計変更の責任が不明確な 状況が発生することもある。具体的には、設計変更要求に対する鉄 骨ファブの意思決定が遅くなり、追加的変更費用が発生した場合、 鉄骨ファブにも責任の一端が生ずる。これらに迅速に対応するため にも、設計変更に対する鉄骨ファブの意思決定の仕組みを改善する 必要がある。

\section{4-2＼cjkstart鉄骨ファブの会議体の仕組み}

鉄骨ファブの設計変更と生産業務に対して実務者のヒアリングと 資料分析により、会議体の仕組み、各会議体の参加者と意思決定の 範囲、会議体の位置付けを詳細に分析した。その結果は既に述べた とおりであるが、調査対象鉄骨ファブが構築している会議体の仕組 みは、設計変更関連対応のものより通常の生産関連対応の会議体の ほうが多く、さらに設計変更対応業務に必要な情報の一部は生産関 連会議体を通じて明確になっている。

このような鉄骨ファブの会議体の仕組みを意思決定の権限と役割 分担の面で見ると、調查対象鉄骨ファブに関しては、機能的組織 (functional organization) 注 ${ }^{6)} の$ 形態から、徐々に分権的組織 (decentralized organization) 注 7)に移行しているとみなすことが できる ${ }^{17)}$ 。すなわち、会社規模の拡大や生産量の増加により、ほと んどの重要な意思決定と業務調整をマネージャーが担当する仕組み から、生産性を高めるため、サブマネージャーを会議体に参加させ る仕組みに変化してきたと考えられる。しかし、これが鉄骨ファブ 一般の傾向か否かは判然としない。

\section{5. まとめと今後の課題}

鉄骨生産システムの合理化における主な課題の一つが設計変更へ の効率的な対応である。本稿では、鉄骨工事の合理的な設計変更対 応体制を検討するために、実際に鉄骨工事の設計変更を担当してい る鉄骨ファブの対応業務とその意思決定の仕組みを詳細に分析した。 また、より円滑な意思決定を行うために、サブマネージャー会議を 導入した事例を取り上げ、導入前後の改善効果と課題を考察した。 その結果、鉄骨ファブがサブマネージャー会議体を導入すること

表 6 鉄骨ファブの各会議体の位置付けと参加者の範囲

\begin{tabular}{|c|c|c|c|c|c|c|c|c|}
\hline & 会長 & 社長 & 副社長 & マネージャ & $\begin{array}{l}\text { サブマネ } \\
\text { ージャー }\end{array}$ & 係長 & 社員 & 会議内容 \\
\hline \multirow{2}{*}{$\begin{array}{l}\text { 設計 } \\
\text { 変更 } \\
\text { 関連 } \\
\text { 会議 } \\
\end{array}$} & & & \multicolumn{2}{|c|}{ 緊急マネージャー会議 } & & & & $\begin{array}{l}\text { 鉄骨生産に大きな影響を与える設計変更 } \\
\text { を検討する緊急にマネージャー会議 }\end{array}$ \\
\hline & & & & & \multicolumn{2}{|c|}{ サブマネージャー会議 } & & $\begin{array}{l}\text { 通常の設計変更対応策と業務調整を検討 } \\
\text { するサブマネージャー会議 }\end{array}$ \\
\hline \multirow{5}{*}{$\begin{array}{l}\text { 生産 } \\
\text { 関連 } \\
\text { 会議 }\end{array}$} & & \multicolumn{6}{|c|}{ 週間会議 } & $\begin{array}{l}\text { 毎週 } 1 \text { 回全部署の主要業務担当者を集めて } \\
\text { 生産日程を整する会議 }\end{array}$ \\
\hline & \multicolumn{3}{|c|}{ 役員会議 } & & & & & $\begin{array}{l}\text { 会社の運営に関する全般的な事項を検討 } \\
\text { する会誐 }\end{array}$ \\
\hline & & \multicolumn{2}{|c|}{ 社長会議 } & & & & & $\begin{array}{l}\text { 生産・設計変更を含めて各部署の業務をチ } \\
\text { エック寸る会議 }\end{array}$ \\
\hline & & & \multicolumn{2}{|c|}{ マネージャー会議 } & & & & $\begin{array}{l}\text { 他部署との業務協力と調整を要する生産 } \\
\text { 関連題を検討する会鸼 }\end{array}$ \\
\hline & & & \multicolumn{5}{|c|}{ 各部署内部会議 } & $\begin{array}{l}\text { 各部署の内部で業務の指示と確認、並びに } \\
\text { 業務調整を行う会議 }\end{array}$ \\
\hline
\end{tabular}


によって、設計変更要求に対して意思決定のプロセスを迅速化し、 設計変更対応業務時間を短縮する効果を上げていることを実証的に 検証した。一方で、この業務改善で注意を要することとして、いく つかの課題を提示した。

今後は、鉄骨ファブの課題として、(1)会議体を効率的に支援する ことが可能な情報システムの確立、(2)会議体の編成・役割分担の明 確化について取り組みたい。

また、鉄骨工事に関わる各生産主体の業務と情報の流れを明確化 し、合理的な設計変更対応体制を構築するという視点では、発注者、 設計者、ゼネコン、そして鉄骨ファブとの設計変更対応業務を含ん だ鉄骨生産システムの一貫管理体制の構築について検討していきた い。

\section{注}

注 1) 日本の「鉄骨製作工場認定制度」に登録されている海外の鉄骨生産工場 は、2011 年現在、約 20 社に至って、中国・タイ・韓国などに所在してい る。

注 2）DCL とは、Design change list と呼ばれる様式の略語であり、設計変 更に関する鉄骨ファブの ISO に規定されており、細部的な内容は会社別で あるが、基本的に変更内容、製作状況、検討 ・ 日付などの記入欄に構成さ れている。

注 3) 会議体とは、正確な意思決定のために、企業内部の業務担当者又は意思 権限を持つ人が集まって行うものである。

注 4）研究対象とした鉄骨ファブでは、各部門長としてのマネージャー、部 下としてサブマネージャーが位置する。しかし、サブマネージャー会議に 参加するサブマネージャーの権限は組織位階とは異なり、各部署内の業務 と役割分担に依存する位置である。

注 5) 分析に使った社内資料は、プロジェクトの生産スケジュール、製作計画、 DCL、製品リスト、部品リスト、現場との打合せ議事録などである。

注 6) 機能的組織とは、外部環境の流動性かつ不確実が低い際には、社内部門 間において業務調整の必要性と困難性も低いため、ほとんどの重要な意思 決定と業務調整を組織階層の上位者としてマネージャーが担当し、個々の 部署は、意思決定に必要とされる情報を十分に持つことが出来ないことが 短所として指摘されている。

注 7)分権的組織とは、組織の各部門の独立性と自律性を持たせた下位組織を 作り、意思決定の権限を分権した組織体制である。また、執権的組織 (centralized organization)の反対概念であり、下位組織間の調整が困難 する場合が多く、役割が不明確になる短所がある。

\section{参考文献}

1) Awad S. Hanna, et.al: Quantitative Definition of Projects Impacted by Change orders, Journal of Construction Engineering and Management, Vol. 128. No. 1, pp57-64, 2002.2

2) William Ibbs: Impact of Change's Timing on Labor Productivity, Journal of Construction Engineering and Management, Vol. 131. No. 11, pp1219-1223, 2005.11

3) William Ibbs, et.al: Quantified Impacts of Project Change, Journal of Professional Issues in Engineering Education and Practice, Vol. 133. No. 1, pp45-52, 2007.1

4）梅国章他：鉄骨製作における分業体制に関する考察、日本建築学会大会 学術講演梗概集、F-1 都市計画 建築経済・住宅問題、pp1287-1288、2010.7

5）金貞坤他：鉄骨生産における情報一貫管理に関する考察、日本建築学会 技術報告集、第 17 巻、第 37 号、pp1037-1042、2011. 10

6) William Ibbs, et.al: Project Change Management System, Journal of Management in Engineering, Vol. 17. No. 3, pp159-165, 2001.7

7) S.H. Lee, et.al: Web-Enabled System Dynamics Model for Error and Change Management on Concurrent Design and Construction Projects, Journal of Computing in Civil Engineering, Vol. 20. No. 4, pp290-300, 2006.7

8) L. Song, et.al: Virtual Shop Model for Experimental Planning of Steel
Fabrication Projects, Journal of Computing in Civil Engineering, Vol. 20. No. 5, pp308-316, 2006.9

9) I.A. Motawa, et.al: An integrated system for change management in construction, Automation in Construction, Vol. 16, Issue3, pp368-377, 2007.5

10）浦江真人他：ファブ-ゼネコン間の連携資料からみた鉄骨製作段階にお ける仕様決定の実態：その 1 仕様の決定の遅れ・変更の発生する部分と その内容、日本建築学会大会学術講演梗概集、F 都市計画 建築経済・住 宅問題、建築歴史・意匠、pp1031-1032、1994.7

11）蟹澤宏剛他：ファブ-ゼネコン間の連携資料からみた鉄骨製作段階にお ける仕様決定の実態 : その 2 鉄骨ファブの工程プロセスと仕様の確定状 況、日本建築学会大会学術講演梗概集、 F 都市計画 建築経済・住宅問題、 建築歴史・意匠、pp1033-1034、1994.7

12）渡辺克己他：鉄骨ファブの業務に関する研究、日本建築学会大会学術講 演梗概集、F-1 都市計画 建築経済・住宅問題、pp1125-1126、1997.7

13）金貞坤他：鉄骨工事における設計変更の発生原因と鉄骨ファブの対応策 日本建築学会、第 27 回建築生産シンポジウム論文集、pp213-218、2011.7

14) G. Karumanasseri, et.al: Decision Support System for Scheduling Steel Fabrication Projects, Journal of Construction Engineering and Management, Vol. 128. No. 5, pp392-399, 2002.10

15) L. Song, et.al: Measuring and Modeling Labor Productivity Using Historical Data, Journal of Construction Engineering and Management, Vol. 134. No. 10, pp786-794, 2008.10

16) ISO9000 resource homepage, http://www.iso9000resources.com/ ba/engineering-change-procedure.cfm/（2011 年 5 月 20 日検索）

17）古川久隆: 組織デザイン論-社会心理的なアプローチ、pp29-33、1988.9 